Or is it simply that any young man engaged in the climb to consultant ranks simply cannot put a foot out of line for fear of being lost for ever overboard? If this is true, and I regret to say I think it is, then is it not high time that the medical profession, and specially the colleges, gave a positive lead in demanding, as is demanded in many other countries, that candidates for "the top" should spend some time working abroad. Failing this lead, very soon we will have no one at home with any experience of work abroad other than those in the specialist tropical and military institutions, and in this day and age of rapid travel worldwide medicine is brought to the doorstep of every doctor in ever larger quantities.-I am, etc.,

$$
\begin{aligned}
& \text { Protestant Hospital, } \\
& \text { Dabou, } \\
& \text { Ivory Coast Republic. }
\end{aligned}
$$

\section{Anticoagulants in Acute Myocardial Infarction}

SIR,-Despite the excellent planning and the abundance of information the M.R.C. report (8 February, p. 335) does not resolve the problem of the value of current conventional oral anticoagulant treatment for acute myocardial infarction. This is because, as the authors suggest, the degree of anticoagulation was not an intense one-that is, 10 to $20 \%$ with Owren's thrombotest method. Many authors have shown that this means much lower anticoagulant dosage than when the Quick test is used and results interpreted from saline dilution curves. ${ }^{12}$ This is also supported by the dosage data in the report.

The thrombotest range equivalent to 15 to $30 \%$ prothrombin activity (1.8 to 3 ratio) with the Manchester (now designated British) comparative thromboplastin reagent is 5 to $10 \%$. Professor Owren aims at $10 \%$ for the treatment of arterial thrombosis, with a range of 7 to $13 \% .^{3}$ Professor Loeliger aims at 4 to $8 \%$ in uncomplicated cases in short-term therapy. ${ }^{4}$ The Manchester (British) reagent is used in routine clinical practice in the majority of hospitals in four regional board areas in England covering a population of 17 million. It is also used as a reference preparation in most other parts of the country.

Among the useful data in the report is the percentage of results below $10 \%$ thrombotest. Only $22 \%$ of patients were below that level. Thus only this proportion of patients were receiving sufficient phenindione to be considered therapeutic. It is therefore only this small proportion of results which can be related to anticoagulant therapy as currently practised in the majority of hospitals in this country.

The authors of the report appear to be aware of this, but it would have been more helpful to the general reader if the findings had been strictly qualified by relating them to the coagulation defect, and stating that the relatively slight coagulation defect represented by 10 to $20 \%$ thrombotest confers no useful benefit in treatment of acute myocardial infarction.-1 am, etc.,

$$
\begin{gathered}
\text { Withington Hospital, } \\
\text { Manchester 20. }
\end{gathered}
$$

Lempert, H., and Poller, L., Lancet, 1960, 2,

Lempert, H., and Poller, L., Lancet, 1960, 2,
2 Sevitt, S., and Innes, D., Lancet, 1964, 1, 124. Owren, P. A., personal communication.

\section{Dermatoses in Lobster Fishermen}

SIR,-In a previous note ${ }^{1}$ it was suggested that a colonial diatom, Fragilaria striatula Lyngb., was strongly indicated as being the active agent causing eczema in a lobster fisherman. At that time the organism did not respond to the culture techniques used and positive evidence could not be obtained.

In the early summer of 1968 a thick coating of the diatoms again developed on lobster pot ropes at Aberdaron. The patient displayed symptoms similar to those previously described. The diatom flora on the ropes again included the Naricula species previously shown to be innocuous, but in the 1968 season the proportion of this organism in the population was much smaller and it proved possible to separate a quantity of uncontaminated Fragilaria from the mass. Culture was again attempted. Two culture solutions were used, both being of the enriched sea water type.

(1) Natural sea water, filtered before storage and again immediately prior to use through a millipore filter of $0.45 \%$ pore diameter, was enriched by the following additions: Sodium nitrate, $12 \mathrm{mg}$./1.; disodium hydrogen phosphate, $0.4 \mathrm{mg}$. $/ 1$. ; ethylene diamine tetra-acetic acid (as ferric salt), $100 \mu \mathrm{kg} / 1$. ; manganese chloride, $20 \mu \mathrm{g} . / 1$. ; vitamin $\mathrm{B}_{1}, 25 \mu \mathrm{g} . / 1$. ; vita$\min B_{12}, 1 \mu \mathrm{g} . / 1$. ; biotin, $1 \mu \mathrm{g} . / 1$. This solution is more fully described by Quraishi. ${ }^{2}$

(2) A more extensively enriched sea water containing additional trace elements as described by Walne ${ }^{3}$ and used by him for the culture of Isochrysis.

Cultures were set up in $250 \mathrm{ml}$. conical flasks and illuminated in constant temperature conditions $\left(15^{\circ}\right.$ C.). Growth occurred on the bottom of all flasks inozulated, but more rapid growth was obtained when chains of cells were inserted into the fibres of a linen thread and suspended in the solution clear of the bottom.

When a pure sample of Fragilaria striatula was used in a patch test a strong positive reaction was obtained. No reaction was observed to patch tests using pure samples of the culture solutions. When the solution in which the cells were grown was filtered and the cell-free solution used in a patch test, there was no reaction. This indicates that the compound causing the reaction is present only in the cells or on their surfaces, and is not an extracellular product which they exude into the surrounding water. Extracts of the diatoms in various organic solvents were also tested; extracts in ethyl alcohol, acetone, and chloroform gave positive reactions, but that in diethyl ether did not.

It can therefore be concluded that the diatom Fragilaria striatula was the cause of the eczema observed in a lobster fisherman at Aberdaron. It is hoped that, by more detailed investigation, the active compound in the diatom cell may be identified chemically.-We are, etc.,

\section{Caernarvonshire and Anglesey}

$$
\text { W. E. BEER. }
$$
Hospital,
Bangor, Caernarvonshire.

W. EIFION JONES.

Marine Science Laboratories,
Menai Bridge, Anglesey.

REFERENCES

Beer, W. E., Jones, M., and Jones, W. E., Brit. med. F., 1968, 1, 807

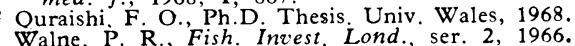
25. No. 4,1 .

\section{Rh Immunization}

SIR,-The report by Dr. W. Q. Ascari and his colleagues on the incidence of maternal $\mathrm{Rh}$ immunization (15 February, p. 399) warrants some comment. After recording the observed incidence of immunization resulting from $\mathrm{ABO}$ compatible pregnancies, they make an estimate of this incidence following ABO incompatible pregnancies. This estimate is derived from data recording the deficiency of $\mathrm{ABO}$ incompatible matings where maternal immunization has occurred. The conclusions drawn are incorrect because the overall effects of $\mathrm{ABO}$ incompatible matings are a compound of the affects of both $A B O$ incompatible and $\mathrm{ABO}$ compatible pregnancies. For example, with the common mating $\mathrm{O}$ mother $\times \mathrm{A}$ father at least $42 \%$ of the children are $\mathrm{ABO}$ compatible. The diminished liability of an individual ABO incompatible pregnancy to immunize is thus not clearly revealed by data which record the overall effect of ABO incompatible matings. Because of this, the estimates given by the above authors for the frequency of immunization by $\mathrm{ABO}$ incompatible pregnancies are too high.

In the Liverpool survey $303 \mathrm{Rh}$-negative primiparae have been tested six months after delivery of their first $\mathrm{ABO}$ incompatible pregnancy, and anti-D has been found in only three instances (expected, if pregnancies were ABO compatible, is 24). Eighty-six of these mothers have been followed through a second $\mathrm{Rh}$-positive pregnancy and three have developed anti-D during this pregnancy (expected, if first pregnancy were ABO compatible, is eight). It is of interest that in all three mothers developing antibodies at this time the second pregnancy was $\mathrm{ABO}$ compatible.

It is generally agreed that even though the risk of ABO compatible pregnancies inducing immunization is considerably diminished compared with $\mathrm{ABO}$ in compatible pregnancies, anti-D gammaglobulin should be given, when supplies allow, to all $\mathrm{Rh}$-negative mothers having Rh-positive babies. It is likely, however, that in some countries supplies will be limited for some years and the ABO relationships between baby and mother might be taken into account in deciding on priorities.

In relation to the use of anti-D during pregnancy one can add to the list of objections given by the authors the likelihood that it will not work. Safe doses of gammaglobulin will be dispersed among the mass of $\mathrm{Rh}$ positive red cells within the foetal circulation, and a danger of an enhancing effect on the mother's immune response cannot be ruled out.-I am, etc.,

$$
\begin{aligned}
& \text { J. C. Woodrow. } \\
& \text { Nuffield Unit of Medical Genetics, } \\
& \text { Department of Medicine, } \\
& \text { University of Liverpool, } \\
& \text { Liverpool } 3 \text {. }
\end{aligned}
$$

SIR,-We have had three instances where the patient could give an accurate description of the obstetric surgeon's conversation during an elective caesarean section (1 February, p. 280 ). We have overcome this problem by giving the patient $10 \mathrm{mg}$. of droperidol, 30 minutes prior to operation. This management has proved entirely satisfactory. There has been no delay in the onset of neonatal 